\title{
Land Conservation and Pest Management of Agriculture Perspective Islamic Religion*
}

\author{
Gunawan Ikhtiono, ${ }^{1}$ Bahagia, ${ }^{2}$ Rimun Wibowo, ${ }^{3}$ Fachruddin Majeri Mangunjaya ${ }^{4}$ \\ 1,2Universitas Ibn Khaldun Bogor, ${ }^{2}$ STIMMA IMMI Jakarta, ${ }^{3}$ Postgraduate School \\ Universitas Nasional Jakarta.
}

10.15408/sjsbs.v7i11.17776

\begin{abstract}
The aim of this research will investigate numerous aspects including agriculture sustainability from an Islamic perspective. The method used is a literature review with descriptive analysis. The result is Islam has several actions to reach farming base on the environment such as the barring of killing some of the animals comprise frog, eagle, bee, and other animal which is valuable for creating ecosystem balance. The action is integrating pest mitigation by way of using nature power to decline the population of insect attacks. The other is to rekindle of land is the most imperative action to assert sustainable agriculture. Lands must be cultivated as people mandatory to God's but don't create killing and vanishing of an animal which bolster soil fertility. For this, the land has to preserve through organic manure to attaint Ihya-Almawat or planting land without ravage soil. The impact is climate change can be encouraged. Then, people who cultivate seed or plant to land, the person will receive a reward from God. While planting plant produces alms as capital for a person when they confront God's. As result, the people on earth obtain some merits such as people get oxygen, shading, habitat for the animal, and save a life from the unpredicted climate.
\end{abstract}

Keywords: Agriculture, Climate, Environment, Islam

\begin{abstract}
Penelitian ini bertujuan untuk mengkaji berbagai aspek termasuk pertanian berkelanjutan dalam perspektif Islam. Metode penelitian yang digunakan adalah pendekatan literature review dengan descriptif analisis. Ada beberapa hasil dari penelitian ini yaitu ajaran Islam memiliki beberapa tindakan untuk mencapai pertanian ramah alam mulai dari larangan membunuh katak, elang, dan lebah untuk menciptakan keseimbangan ekosistem. Warisan ajaran ini mengintegrasikan pengendalian hama dengan kekuatan alam. Warisan jaran yang lain yaitu menghidupkan lahan agar lahan tetap produktif dan berkelanjutan. Tanah harus diolah sebagai namun tidak menciptakan pembunuhan dan pemusnahan hewan yang menyebabkan tanah menjadi gersang. Untuk itu, tanah harus diawetkan melalui pupuk organik untuk mencapai Ihya-Almawat atau tanah tanam tanpa merusak tanah. Kemudian, orang yang membudidayakan tanaman akan menerima pahala berupa sedekah. Terdapat beberapa sedekah seperti makhluk hidup mendapatkan oksigen, bisa berteduh, menjadi habitat hewan, dan menyelamatkan kehidupan dari iklim yang tidak terduga.

Keywords: Pertanian, Iklim, Lingkungan, Warisan Islam
\end{abstract}

* Received: July 3, 2020, Revision: July 28, 2020, Published: November 1, 2020.

${ }^{1}$ Gunawan Ikhtiono is a lecturer at Universitas Ibn Khaldun Bogor.

${ }^{2}$ Bahagia is a lecturer at Universitas Ibn Khaldun Bogor.

${ }^{3}$ Rimun Wibowo is a lecturer at STIMMA IMMI Jakarta.

${ }^{4}$ Fachruddin Majeri Mangunjaya is a Postgraduate School Universitas Nasional Jakarta. Corresponding Author E-mail: bahagiagia59@yahoo.co.id. 


\section{A. INTRODUCTION}

Indonesia confronts some obstacles in achieving agriculture friendly to nature. To the production of rice and vegetable, the farmer still applicate pesticide which impacts to devastate the environment and ecology. Even it distribute the adverse impact to human health when the people consume the agriculture product which contains the pesticide. People or farmers can suffer some disadvantages of a pesticide including vomiting, nausea, dizziness, and break the skin ${ }^{5}$. Besides, using pesticides can experience skin irritation, itching, and burning 6 . It can be exacerbated by pesticides lead to poison the environment, kill the natural enemy or predator, and resistant to insects ${ }^{7}$. The usage of excessive pesticides can harm the environment like water and soil ${ }^{8}$. Pesticide damage human health through inhaling, skin contamination, and oral track as well as when exerting excessive dosage, the human can experience death'. However, the disadvantage of pesticide, Famer still select pesticide as a venue to combat pest because it finds easily, availability, can kill a pest immediately, and can react hight success in vanishing pest ${ }^{10}$.

The behavior like utilizing of pesticide must be vanished and continue to adopt organic and applicate nature enemy (biological control) for protecting the plant from an insect. It can preserve the environment from devastating and conserve environment function because pesticide also hurts reducing the rate of a predator in nature. While nature enemy has a pivotal role in controlling the pest population. Besides that, agriculture production contributes to damaging the climate. The input of agriculture like fertilizer is a cause of global warming where the rate of temperature in the earth can jump. The highest sources of emissions in the agricultural sector come from the use of fertilizers, livestock, paddy fields, livestock waste, and burning of agricultural residues ${ }^{11}$. There is numerous effect of global warming including unpredicted rainy season pattern, disaster (flooding and drying), the rising level of the sea and emerging of temperature rate on earth.

This greenhouse gas becomes a layer that covers the earth so that it hinders the re-reflection of sunlight from the earth into the atmosphere. The thicker green gas emission increases the temperature on the surface of the earth thereby increasing

${ }^{1}$ E. Amilia, B. Joy, \& Sunardi, Residu Pestisida pada Tanaman Hortikultura (Studi Kasus di Desa Cihanjuang Rahayu Kecamatan Parongpong Kabupaten Bandung Barat), Jurnal Agrikultura 27, No1, 2016, h.23.

${ }^{6}$ V.M. Miana \& C. Suraji, Penggunaan Pestisida Berhubungan Dengan Iritasi Kulit Pada Petani Padi, Jurnal Ilmiah Permas: Jurnal Ilmiah STIKES Kendal 10, No.1, 2020, h. 51.

${ }^{7}$ M. Flora, O. Singkoh \& D.Y. Katili, Bahaya Pestisida Sintetik (Sosialisasi Dan Pelatihan Bagi Wanita Kaum Ibu Desa Koka Kecamatan Tombulu Kabupaten Minahasa), Jurnal Anak Perempuan Indonesia 1, No.1, 2019, h.5.

${ }^{8}$ A. Arif, Pengaruh Bahan Kimia Terhadap Penggunaan Pestisida Lingkungan, JF FIK UINAM 3. No.4, 2015, h.134.

${ }^{9}$ Mansur, Dampak Sosial Penggunaan Pestisida Bagi Petani Persfektif Sosiologi Pedesaan, Al-Munzhir: Jurnal Kajian Ilmu Komunikasi dan Bimbingan Islam 6, No.1, 2013, h.69.

${ }^{10}$ W. Yuliyanah \& W. Meikawati, Hubungan Pengetahuan Tentang Bahaya Pestisida, Pendidikan Dan Sikap Dengan Praktik Penggunaan Alat Pelindung Diri (Apd) Pada Petani Bawang Merah, Jurnal Kesehatan Masyarakat Indones 10, No. 2, 2015, h. 82.

${ }_{11}$ M. Sudarma \& A.R. As-syakur, Dampak Perubahan Iklim Terhadap Sektor Pertanian Di Provinsi Bali, Journal on Socio-Economics of Agriculture and Agribusiness 12, No.1, 2018, H. 89.

978 - Fakultas Syariah dan Hukum UIN Syarif Hidayatullah Jakarta 
global heat. Agricultural development is exacerbated by the scarcity of youth farmers. A productive farmer or young age continues to decline but the production of agriculture must involve the young generation to pursue agriculture action. Youth are more interested in working in industry and commerce. The fact is the failure of farmers to regenerate has an impact on agricultural production. Meanwhile, the state of art in farming has been found, it is not optimal yet so it needs farmers. Even to operate a tractor can not be separated from human power and skill as well as knowledge. Decreasing the number of youth's interest in farming because agriculture is perceived as damaging to appearance especially women and has a low social status ${ }^{12}$. On the other hand, agricultural development without an actor or executor is deemed impossible to produce food.

In this research, there are several objectives that the researcher will be investigated including how Islamic heritage has a contribution to the friendly environment in agriculture such as how Islamic teaching protects the soil environment. In this principle, the soil is alive because of the presence of soil supporting organisms so that the soil is more alive when planted with plants. Besides, how Thya-Almawat or revive dead soil as a step to protect the environment based on Islamic heritage. The other is Islamic heritage have a pivotal role to achieve agriculture free using of pesticide which brings disadvantage to the environment including soil, water, air, and human as well as extinguishing important biological control of pest in nature. The other purpose is to find the connection of Islamic view about the prohibition of consumption of some bird and animal to reduce the rate of attack pest. Islam has banned killing animals such as frogs and prohibited consuming animals that are made such as eagles and owls. Both birds have an important role as pest predators. The role of the eagle is to control the pest of mice.

When these birds are forbidden to be consumed, there is a value that it can use as pest control ${ }^{13}$. Owl birds are gripping birds that can decline the percentage of mice until 70 percent or one owl can eat around 3-5 mice each night ${ }^{14}$. Bird-like alap-alap and eagle hit their prey through gripping ${ }^{15}$. Even the principle of halal and haram prohibitions as a way of environmental conservation ${ }^{16}$. Besides, environmental conservation by greening the land including how to preserve the environment. When the land is greened with trees, the land will be preserved. Islam views that planting seeds or trees is part of worship, it is considered to be alms. Someone cultivate plants, these plants will be used for living things. At least the tree produces oxygen for the planter as well as the living creature on earth. After that, the job of being a farmer is classified as a very noble job because it is a behavior to provide food for all humanity.

${ }^{12}$ C.S. Werembinan, C.B.D. Pakasi \& L.R. J. Pangemanan, Persepsi Generasi Muda Terhadap Kegiatan Pertanian Di Kelurahan Buha Kecamatan Mapanget Kota Manado, Agri-SosioEkonomi Unsrat, 14, No. 3, 2018, H.123.

${ }^{13}$ Bahagia, Pembangunan Pertanian dalam Islam, IPB Press, 2014, H.131.

${ }^{14}$ N. M. S. Sukmawati, N.W. Siti \& N.N.Candraasih, Pengembangan Burung Hantu (Tyto Alba) Sebagai Pengendali Hama Tikus Di Desa Babahan Dan Senganan, Penebel, Tabanan, Bali, Buletin Udayana Mengabdi, 16, No. 1, 2017, H.92.

${ }^{15}$ Bahagia, Manusia, Lingkungan Alam dan Pembangunan, SUKA Press, 2014, H. 159.

${ }^{16}$ F.M. Mangunjaya, Konservasi Lingkungan Dalam Islam, Pustaka Obor Indonesia, 2020, H.110. 


\section{B. METHODS}

Research with the topic of land conservation and pest management of agriculture perspective on Islamic Religion using a literature review and descriptive approach. This literature review aims to build and construct a stronger conception based on empirical studies that have been conducted ${ }^{17}$. By studying other people's studies, we can determine whether to imitate, repeat, or criticize a particular study. We use the studies of other people as a comparison for our studies ${ }^{18}$. Research activities are carried out by collecting information and data with the help of various materials in the library such as reference books, similar previous research results, articles, notes, and various journals related to the problem to be solved ${ }^{19}$. The data collection procedure in this literature review is by using keywords in searching for material to be used in the literature review, then reading, summarizing, and compiling the material that has been obtained.

Meanwhile what is meant by descriptive research is where the data that has been obtained is analyzed in-depth and then described narratively so that it is easy to understand and can provide accurate information ${ }^{20}$. In this study, the sources of research data were obtained from various sources such as the hadith, the Al-Quran, and research journals that have been published with SINTA index, Scopus, and accredited research journals. The data obtained are related to Islamic religious values which are derived from the hadith and Al-Quran. Then make a connection between the research findings and religious values. Finally, data can be presented scientifically because what is contained in the value of religion can become scientific if it is connected with facts and findings of previous research.

\section{RESULTS AND DISCUSSION}

\section{Management Land and Conservation in Islamic}

Humans have mandatory to rekindle dead land as proof that people run the task on earth. The land has been rendered to humans for cultivating some plants and conduct conservation on earth to ensure the sustainability of nature function for the human future. The land is said to be abandoned if there are no visible buildings,

17 H.K. Tjahjono, Studi Literatur Pengaruh Keadilan Distributif dan Keadilan Prosedural Pada Konsekuensinya Dengan Teknik Meta Analisis, Jurnal Psikologi, 35, No.1, 2015, H.21.

${ }^{18}$ A. Marzali, Menulis Kajian Literatur, Jurnal Etnosia, 01, No. 02, 2016, H.28

${ }^{19}$ M.Sari \& Asmendri, Penelitian Kepustakaan (Library Research) dalam Penelitian Pendidikan IPA, Natural Science: Jurnal Penelitian Bidang IPA dan Pendidikan IPA, 6, No.1, 2020, H.44.

20 M. Khoiron \& V. Rezania, Studi Literatur Tentang Pengaruh Penggunaan Media Monopoli Modifikasi Terhadap Hasil Belajar Ips Siswa Sekolah Dasar, Prosiding Seminar Nasional Rekarta 2020 Menciptakan Inovasi Pendidikan Melalui Kompetensi Pendidik Menuju Kemandirian Bangsa Di Era 5.0, 2020, H.133 
people cultivating, planting, and building fences ${ }^{21}$. Abandoned land can be called the land that is not empowered, managed, utilized, and cultivated by humans ${ }^{22}$. The command to revive the dead land and prevent the land from dying is one of the duties of humans after humans are trusted to manage the earth and its sides. As a Caliph, a man plays the role of leader for the entire universe. At the same time, there is a role as a human being to protect the earth, utilize the landscape, and at the same time carry out environmental conservation.

In Al-Quran, Allah has appointed humans as the Khalifah for the prosperity of whole living creature. We have reserved the trust in all heaven and earth and the mountains. So all are hesitant to carry the mandate and they are worried that they will betray it, and that the mandate is shared by humans. Indeed, humans do a lot of wrongdoing and are severely silly (Qs Al-Ahzab: 72). Besides, Allah says that God has invented human beings from the soil and makes human beings as actors for worthy (QS Huud 11:61). Allah also remarked that "Do not invent mischief on the face of the earth," they answer: "Indeed we are the ones who make alleviating." (Surat al-Baqarah 2:11).

The Al-Quran and the hadith above describe that humans are ordered to revive the dead land and not abandon the land that has been created for humans and all of this world. However, damage to the soil and the environment must be properly avoided because it causes environmental disasters to humans. Turning on dead soil means that humans plant the soil so that the land appears alive because there is a human activity and there is a form of that action. When the land is planted with rice, fruits, and vegetables, it is classified as an activity to revive the dead land because the land is productive and valuable. At least there are social, economic, and ecological values when one lives the dead land. Socially, when the land is turned on, the produce from the land is useful for empowering others. Suppose the results are given to people classified as needy, including orphans, widows, poor, needy, and needy. However, the land is unsustainable if there is no soil preservation or conservation.

So the land that is often planted without paying attention to the carrying capacity of the soil will damage the soil. Even the lands that are often turned into floods and droughts. If the land has experienced dryness, the land can't produce again unless it is used for other purposes than agriculture. So the land can experience death even though it has been revived by humans because if it is too greedy to revive the land, the land will die. Allah has reminded people of various verses of the Quran including QS Ar-Rum 30:41 and Al-Baqarah 2: 205. These two verses describe environmental damage due to human behavior. One of the ways to revive damaged land is to see the way indigenous people to revive the land. The Urug customary community in Bogor is reluctant to revive the land by planting rice more than 2-3 times. They grow rice once a year using local rice.

${ }^{21}$ Mujahidin, Konsep Iqtha' Pemberian Tanah Kepada Masyarakat Dalam Pemikiran Ekonomi AlMawardi (Studi Kitab Al-Ahkam Alsultaniyyah), Al-Amwal: Journal of Islamic Economic Law, 2, No. 2017, h. 6

${ }^{22}$ A. Munif, Ihyyā' al-Mawāt dalam Kerangka Hukum Pertanahan di Indonesia, Al-Ahkam, 29, No. 1 ,2018, h.89. 
The main goal is to avoid greed and at the same time to maintain the function of the land so that it is not damaged by being forced to produce by planting ${ }^{23}$. When the land is planted continuously without giving manure and allowing the land not to be planted, the nutrients that are lost due to erosion and plants are not replaced. In this case, humans must get the maximum benefit from nature but minimize the possible risks ${ }^{24}$. The cause of soil damage so that the soil becomes dead is none other than human behavior. The land becomes dead because of the function of the biotic (living things), a-biotic (inanimate parts), and cultural (humans and their behavior) components. There is human behavior that does well to the environment such as soil and some do not conserve or preserve the soil environment but get benefits from the soil.

This condition is often called where the environment does not reach an imbalance so it is impossible to be sustainable. The environment is said to be balanced if all the biotic and abiotic components are in the proper amount in the amount and role in the environment ${ }^{25}$. There are three environments, namely the biotic environment (living things), the abiotic environment (an inanimate environment), and the human environment (cultural). One of the most important factors in the a-biotic factor is soil ${ }^{26}$. The soil component as an a-biotic environment interacts with the biotic environment and humans as the manager of the land. In soil management, these three components must be considered. Soil that has been turned on will be poor in nutrients, arid, there will be floods in the land due to incorrect cultivation of the land or land so that critical lands appear.

Even though the earth was fertile in the beginning, the result of the human component did not pay attention to the three components, in the end, the soil was damaged. The impact of degraded land is a decrease in soil quality, in addition to reducing the conservation, production, and socio-economic functions of the community ${ }^{27}$. The main problem of this arid land is because living things in the soil cannot move due to the food source provided in the form of poison to worms and various types of decomposers in the soil. Soil is categorized as a habitat for various organisms and soil organisms that act as decomposers of matter, distribution, and mixing of organic matter ${ }^{28}$. If poison content in pesticide is used to control pests, it kills

${ }^{23}$ Bahagia, Traditional Knowledge Of Urug Community For Climate, Conservation, And Agriculture, Mimbar: Jurnal Sosial Dan Pembangunan, 36, No.1.

${ }^{24}$ S. Suwandi, A. Yunus, \& L. Etika, Kecerdasan Ekologis Dalam Buku Sekolah Elektronik Mata Pelajaran Bahasa Indonesia Smp, Litera, 15, No. 1, h.26

${ }^{25}$ R. Wulandari, Metode Kunjungan Lapangan Untuk Menanamkan Kepedulian Terhadap Lingkungan Hidup, Jurnal Pedagogia 5, No. 1, 2016, h. 73.

26 D.G. Rahmawanto, A.Muhibuddin, L.Q.Aini, Pengaruh Faktor Abiotik Kimia Tanah Terhadap Supressifitas Tanah Dalam Mengendalikan Penyakit Layu Bakteri (Ralstonia Solanacearum) Pada Tanaman Tomat (Lycopersicon Esculentum Mill), Jurnal Hpt, 3, No. 2, 2015, H.2.

${ }_{27}$ D. Indrihastuti, K. Murtilaksono \& B. Tjahjono, Analisis Lahan Kritis Dan Arahan Rehabilitasi Lahan Dalam Pengembangan Wilayah Kabupaten Kendal Jawa Tengah, Tata Loka 18 No. 3, 2016, H.141.

${ }^{28}$ Sakiah, A. Firmansyah, \& D. Arfianti, Sifat Biologi Tanah Pada Lahan Aplikasi dan Tanpa Aplikasi Tandan Kosong Kelapa Sawit di Adolina PT. Perkebunan Nusantara IV Soil Biological Characteristics on Land With and Without The Application of Oil Palm Empty Fruit Bunch At Adolina PT. Perkebunan Nusantara IV, Jurnal Penelitian Pertanian Terapan, 20, No. 1, 2020, h.12. 
earthworms and decomposers directly. Every pesticide grain that flies into the air as a result of being sprayed, some of the granules will enter the soil. At that time, one by one the living things that determined soil fertility became extinct.

Earthworms act as decomposers, making holes for soil pores because earthworms have a behavior where earthworms will throw dirt onto the soil surface. Directly the holes made by the earthworms are useful for controlling flooding when it rains. There are related interactions between components in the environment so that they cannot be separated, if there is damage to one part, for example, the a-biotic environment, then it will prevent other components such as environmental biotics. Soil biota such as worms leaves due to limited dietary factors because abiotic factors (temperature, temperature, humidity, soil) do not support the life of earthworms, which in turn can cause stress on these organisms, migration, and adaptation to the environment ${ }^{29}$. One measure of soil fertility if there is a very large population of organisms in the soil so that the soil is chemically and physically correct ${ }^{30}$. It is different if the land is given organic fertilizer.

Soil microorganisms are very beneficial because they have a role to destroy organic waste, plant nutrient cycling, nitrogen fixation, phosphate solvents, stimulate growth, and help nutrient absorption ${ }^{31}$. Giving organic fertilizers can reduce environmental pollution, sustainably improve land quality, and increase the quality and production of plants $^{32}$. Several organic fertilizers can be used including compost, manure, and green manure. This organic matter is expected to improve soil fertility through its role in soil physical, chemical, and biological properties ${ }^{33}$. Organic fertilizers will trigger the arrival of soil microorganisms. Besides, the soil is good if there are soil pore holes. Furthermore, Islam has implemented Ihya-Almawat as the most imperative action to rekindle land. In Arabic, living dead land is called Ihya almawat. It means making productive untreated land productive, both for housing and for agriculture. In the land, there are assortement inlucidng biotic and a biotik component. Both of them mutual interaction. Returning organic material into the soil is very beneficial for the environment. The rising number of organic soil has a positive

${ }^{29}$ S. Dwiastuti, Pemberdayaan Lahan Kritis melalui Pola Interaksi Cacingtanah dengan Lingkungannya, Proceeding Biology Education Conference 14, No. 1, H.26

30 Susilawati, Mustoyo, E. Budhisurya, R.C.W. Anggono, Bistok H. Simanjuntak, Analisis Kesuburan Tanah Dengan Indikator Mikroorganisme Tanah Pada Berbagai Sistem Penggunaan Lahan Di Plateau Dieng, 25, No. 1, 2013, H. 66.

31 A. Tarmeji, R. Shanti \& Patmawati, Hubungan Bahan Organik dengan Keberadaan Fauna Tanah pada Umur Rehabilitasi Lahan Pasca Tambang yang Berbeda, Jurnal Agroekoteknologi Tropika Lembab, 1, No. 1, 2018, H. 8.

32 A.D. Nusantara, Y.H. Bertham, A. Junedi, H. Pujiwati, \& Hartal, Pemanfaatan Mikroba Untuk Meningkatkan Pertumbuhan Dan Hasil Kedelai Di Tanah Pesisir, Jurnal Ilmu Pertanian Indonesia, 21, No.1, 2019, H.38.

${ }^{33}$ I. Putra \& M. Jalil, Pengaruh Bahan Organik Terhadap Beberapa Sifat Kimia Tanah Pada Lahan Kering Masam, Jurnal Agrotek Lestari 1, No. 1, 2015, H.28. 
impact on soil fertility, seed production and plant biomass ${ }^{34}$. Applicating agriculture organic can absorb from Low External Input Teknologi (LEIT).

The technology exerts composting and organic fertilizer and decrease implementing factory fertilizer and pesticide ${ }^{35}$. It is encouraged by using local resources like organic sources locally ${ }^{36}$. The use of organic agricultural inputs contributes to reducing emissions by $10-25 \%{ }^{37}$. Conversely, the use of non-organic fertilizers such as nitrogen-containing fertilizers has an impact on the environment. Nitrogen-containing fertilizers contribute to the production of greenhouse gases (GHG) globally because it is a source of nitrous oxide (N2O) production ${ }^{38}$. Greenhouse gases that cause global warming include carbon dioxide (CO2) and methane (CH4). Emerging of greenhouse gas emissions in the atmosphere leads to a jump in air temperature. It directly makes the environment more difficult to predict, especially during the period of rain. It is compounded by the number of disasters that occur everywhere $^{39}$. The agricultural sector through the use of inorganic fertilizers includes sectors that produce Emissions. Islamic teaching has applied organic agriculture which is the best solution to preserve and to create land is life.

The announcement to rekindle the land have been mentioned in Musnad Imam Shafi'iy. From Hisham, from his father that the Prophet said that"Whoever raises the dead land, the land is for him, and there is no right for those who persecute (want to master the land rights) (Musnad Imam Shafi'iy: 755). However, people encourage to tillage soil but they must pay attention to some aspects. It can see in Hadits, from Tariq, said: "I have heard Said Ibn Al-Musayyab said, It is not allowed to plant crops except in three places: First, in his land, second in the land which is cultivated which is handed over to him and the third island that is rented with gold or silver. (HR Nasa'iy). The purpose of reviving dead land is related to activities carried out by humans on land. Land that should not be abandoned should be used and not allowed to be left untreated. Moreover, letting the land become abandoned land untreated for up to 3 years, it must be returned to the state.

${ }^{34}$ Munandar, F. Gustiar, Yakup, Hayati, R. 2014. Sistem Pertanian Terpadu Biocyclofarming Sebagai Alternatif Teknologi Budidaya Pertanian Rendah Emisi Gas Rumah Kaca Untuk Mitigasi Dampak Perubahan Iklim Global. Jurnal Buana Sains, 14, 2, 131-139.

${ }^{35}$ I. Setiawati, A. Muharam, A. Susanto, E. Boes, A. Hudayya, PenerapanTeknologi Input Luar Rendah Pada Budidaya Cabai Merah untuk Mengurangi Penggunaan Pupuk dan Pestisida Sintetik (Implementation of Low External Input Technology for Chili Pepper Cultivation to Reduce Fertilizer and Synthetic Pesticide), Jurnal hortikultura, 28, No. 1, 2018, H.113.

${ }^{36}$ Nuraini, Yuwariah \& Rochayat, Pengembangan Produksi Pertanian Lahan Kering Dengan Sistem Low External Input Sustainable Agriculture (Leisa) Di Desa Cigadog, Dan Mandalagiri Kecamatan, Leuwisari Kabupaten Tasikmalaya, Jurnal Dharmakarya:Jurnal Aplikasi IPTEK untuk masyarakat, 4, No.2, 2015, H.113.

${ }^{77}$ M. Najamuddin, Strategi Mitigasi Emisi Gas Metan Pada Budidaya Padi Sawah. Jurnal Agribisnis,. 8, No. 2, 2014, H.176.

${ }^{38}$ B. C. Erbas \& E.G. Solakoglu, In the Presence of Climate Change, the Use of Fertilizers and the Effect of Income on Agricultural Emissions, Jurnal Sustainability 9, No.1989, 2017. H. 3.

${ }^{39}$ D.K. Yuliana, Greenhouse Gas Emission Level In Indramayu District Tingkat Emisi Gas Rumah Kaca Di Kabupaten Indramayu, Jurnal Sains Dan Teknologi Mitigasi Bencana, 12, No. 2, 2017. Hal. 2. 
This method is too intent for the emerging spirit of people not to let land useless and land must be productive. On one side, lands can become dead land if they are wrong in providing agricultural inputs. The land can be dead as human attitude still relies on inorganic fertilizer to revive the land. The activity of reviving dead land also does not contribute to global warming due to the use of organic inputs. It distinguishes when the farmer or human exert inorganic chemical fertilizers, the soil experiences chromatin and increase death land. Meanwhile, Allah has reminded humans where they must retain their behavior not to devastate the environment through reviving land with agricultural activity. In Al-Quran, and do not make mischief on the face of the earth, After (Allah) corrects it and pray to Him with fear (will not be accepted) and hope (will be granted). Surely the grace of Allah is very close to those who do good (QS AlA'raf 56).

In this, humans are not allowed to damage the land and contribute badly to climate-related to the sustainability of the mandate from God. Humans have become Khalifah or prosperous earth. When land is cultivated continuously with inorganic input, environmental damage is accompanied. Another value about reviving soil based on Islam is to indicate that land has connected to humans and humans don't admit to ravage the soil through reviving. They must applicate an organic manner and try to conserve soil. When adopting organic behavior, it continues to preserve soil from damaged. Besides, the greening of land is an important aspect to conserve soil future. The perpetrator obtains a reward for the preservation of the land. In hadist, from Abu Hurairah, Rasulullah Saw said, "A person who plants a seed and then the results are eaten by birds, wild animals and stolen by humans counts as worship and Alms (HR Imam AlBukhari). Planting can be categorized as worship and alms. Besides, Forests have a pivotal role in ensuring water for people, abolishing emissions from the atmosphere, producing oxygen, and conserving numerous species of plants ${ }^{40}$. While charity is classified as uninterrupted worship despite the person have been dead. Conversely, human has the burden to responsible for a task as failure to revive land where ecological problems occur including climate change, disrupt life, and destroy living things, including human error.

\section{Pest Management In Islamic View}

Pest control using pesticides hurts the environment including polluting water, soil, air, and harming humans because humans can get sick and get poisoned due to consuming agricultural products that contain pesticides. Plus pesticides cause pollinating insects and predatory insects to become extinct because they die together when farmers control pests and diseases. The situation will worsen because pests can adapt to the environment, causing resilient insects to face an unsuitable environment. As a result, farmers have to pay dearly for this problem and they have to spend even more money to buy other types of pesticides with different trademarks. When the

40 Bahagia bahagia, F.M. Mangunjaya, R. Wibowo, Z. Rangkuti, M.A. Alwahid, Leuit and prohibition forest: Indigenous knowledge of an Urug community resilience, Harmoni Sosial: Jurnal Pendidikan 7, No. 2, 2020, H. 135. 
environment has been damaged, such as the extinction of various insects, including natural enemies, the pests can no longer be controlled.

This behavior is due to a lack of awareness of environmental functions and wants to quickly see the effects of the workings of pesticides which can kill pests directly. This method is contrary to the goal of sustainable agricultural development where humans must protect nature through agricultural activities. The most severe impact is that farmers experience poverty because agricultural products are not profitable but have to spend more capital than the profits they get. To realize the development of nature-friendly agriculture, farmers must begin to return to organic pesticides and carry out religious orders to control pests. Organic pesticides have many advantages including the ingredients are easily vanish in nature, the impact is the product becomes safe to consume, organic pesticides don't toxic, don't create insect resistance, and gain benefit economically ${ }^{41}$.

Control in this way must be supported by pest control using natural predators. Nature's enemy can come from birds and insects. In Islam religion concept of recommended food and prohibition for food can be utilized for controlling the pest. Whereas pest control in Islamic teachings is realized by utilizing top predators in nature through the prohibition of consuming wild birds. These birds include eagles, kings, and owls. This bird belongs to the population control or pest control of mice on various types of plants. The rising of the mice population because of the a-biotic environment and sanitation. Abiotic factors affect, among others, cropping systems, habitat sanitation, and the behavior of the farmer. Habitat sanitation refers to the cultivation of ex-harvested land and the land around the rice fields that must be cleared, as well as cleaning weeds, cleaning irrigation channels around the rice fields ${ }^{42}$. To decline the number of mice can exert owl.

Treatment using this predator is considered quite effective, efficient, and has no environmental impact on agricultural land, agricultural products, and health impacts on farmers ${ }^{43}$. Islamic teachings contribute to realizing environmentally friendly pest control by regulating consumption behavior. Provisions on Halal and Haram consumption patterns in consuming natural resources including pest control methods. In terms of language, haram is prohibited/prohibited or not permitted. In terms of terms, haram something that God forbids to do with a strict prohibition, everyone who opposes it will face the torment of Allah in the hereafter.

In the hadith, from Ibn 'Abbas, he said, Rasulullah SAW. bane during khaibar war for eating every fanged beast and forbid eating every bird with sharp hooves. (HR

${ }^{41}$ W. Astuti \& C.R. Widyastuti, Pestisida Organik Ramah Lingkungan Pembasmi Hama Tanaman Sayur, Rekayasa, 14, 2, 2017, h. 117.

42 D.K. Primadani1, B. Istiaji, S. Priyambodo, A. Sanmas, N. Fauzana, T. Nurhawati, A. Rosidah, A. Ardella, D.A. Rahmadhani, I. Sukmawati, L.D. Pratiwii, Potensi Pemanfaatan Burung Hantu Sebagai Pengendalian Tikus Sawah di Desa Bener, Kecamatan Wonosari Kabupaten Klaten, Jurnal Pusat Inovasi Masyarakat 2, 2, 2020, H.282.

43 J. Setiabudi, M. Izzati \& Kismartini, Analisis Prioritas Kebijakan Pemanfaatan Burung Hantu (Tyto Alba) Sebagai Pengendalian Hama Tikus Sawah Yang Ramah Lingkungan Di Kabupaten Semarang, Indonesian Journal of Conservation 04, No. 1,2015, H.68. 
Ibn Majah). Some types of animals such as birds with sharp and hoofed beasts are prohibited to consume. In some research, Adult owls can eat as many as 2 - 5 mice per day and can attack prey from a distance of 500 meters $^{44}$. One Tyto alba owl can eat 3-5 mice per night with a flight radius of up to $12 \mathrm{~km}$. Based on the results achieved, it can be concluded that Tyto alba is very effective to use as rat pest control ${ }^{45}$. The use of owls in eradicating rat pests is considered safer by building owl houses (pagupons) in the middle of rice fields rather than using snake predators. Thus a rice field ecosystem is formed ${ }^{46}$. Besides that, manifesting good deeds or good behavior to all living things such as the prohibition of killing frogs. Frogs play a role in maintaining ecosystem balance through suppressing insect populations. In the hadith, from Abdurrahman bin Uthman that a doctor is mentioning a frog as a medicine in the presence of the Prophet sallallaahu 'alaihi wasallam, then he forbade from killing him. (HR An-Nasai).

Frogs and toads as amphibian animals have an important role in the environment, including maintaining the balance of the ecosystem. Amphibians have great potential to deal with insect pests (cybernetic) because the main feed of amphibians is insects and larvae. The role of frogs in nature is to control insect populations and ecological controllers. The insects eaten by frogs come from the order Hymenoptera family of the family Formicidae ${ }^{47}$. This makes it important to control insects that harm humans ${ }^{48}$. One of the meanings of the prohibition on killing frogs and toads in Islam has a value that is maintaining the balance of the ecosystem. Frogs don't only consume important agricultural pests such as planthopper, grasshoppers, ladybugs, and types of flies. Frogs also play a role in controlling mosquito populations. In the end, diseases transmitted from vector insects such as mosquitoes can be controlled.

\section{CONCLUSIONS}

Land management and conservation are carried out by reviving the dead land so that the land or soil remains productive. The land is said to be alive if the land has been cultivated by humans. When the land is alive, it can become dead land when the land is cultivated wrongly. The land must be turned on with environmentally friendly agricultural inputs, namely using organic fertilizers rather than inorganic fertilizers.

${ }^{44}$ M.D. Pusparini \& I.K. Suratha, Efektivitas Pengendalian Hama Tikus Pada Tanaman Pertanian Dengan Pemanfaatan Burung Hantu Di Desa Wringinrejo Kecamatan Gambiran Kabupaten Banyuwangi, Provinsi Jawa Timur, Jurnal Pendidikan Geografi Undiksha, 6, No. 2, 2018, H. 54 \& 56.

45 N. M. S. Sukmawati, N.W. Siti, N.N.Candraasih K, Pengembangan Burung Hantu (Tyto Alba) Sebagai Pengendali Hama Tikus Di Desa Babahan Dan Senganan, Penebel, Tabanan, Bali, Buletin Udayana Mengabdi, 16, No. 1, 2017, H. 92.

${ }^{46}$ F. Ardigurnita, N. Frasiska, E. Firmansyah, Burung Hantu (Tyto alba) Sebagai Pengendali Tikus Sawah (Rattus argentiventer) di Desa Parakannyasag Kota Tasikmalaya. Jurnal Abdimas Kartika Wijayakusuma 1, No. 1, 2020, H.57

${ }^{47}$ M. Wati \& Y. Hidayat, Komposisi Makanan (Diet) Dua Spesies Kodok Bufo Melanostictus, Schneider (1799) Dan Bufo Asper, Gravenhorst (1829) Di Daratan Tinggi Dan Dataran Rendah Sumatera Barat, jurnal pelangi, 6, No.2, 2014, H. 152\&154.

48 S.N. Utari, N.F. Haneda, M.D. Kusrini, Potensi Kodok Buduk (Duttaphrynus Melanostictus Schneider 1799) Sebagai Pengendali Alami Hama Di Daerah Urban, 25, No.1, 2020, H.15. 
The use of this fertilizer will make these lands live and avoid becoming arid and dry. Land can become dead because it consists of various constituents, namely biotic, abiotic, and human components. When the land does not use organic input, the biotic components of the soil can die so that the land becomes barren and plant production decreases.

Soil biotic components include earthworms, when the soil is fertilized with organic fertilizers, the worms remain living things so that they support the land to stay alive. Besides, pest control is based on the prohibition of not consuming birds with sharp nails and claws. Likewise the prohibition against killing some animals such as frogs. Meanwhile, frogs play an important role in pest control and insect population control. Meanwhile, when pest and disease control is carried out by using pesticides, frogs die, so that the pest population increases. It is different when controlling pests and diseases by using natural predators such as frogs, the environment is not damaged.

\section{REFERENCES}

Adiba, Arif. "Pengaruh Bahan Kimia Terhadap Penggunaan Pestisida Lingkungan, dalam ", dalam jurnal Jf Fik Uinam 3. No.4, 2015.

Ahmad Munif, "Iḥyā' al-Mawāt dalam Kerangka Hukum Pertanahan di Indonesia", Al-Ahkam, 29, No. $1,2018$.

Amilia, Euis.; Joy, B.; \& Sunardi. "Residu Pestisida pada Tanaman Hortikultura (Studi Kasus di Desa Cihanjuang Rahayu Kecamatan Parongpong Kabupaten Bandung Barat)", dalam Jurnal Agrikultura 27, No1, 2016.

Ardigurnita, Firgian.; Frasiska, N.; Firmansyah, E, “Burung Hantu (Tyto alba) Sebagai Pengendali Tikus Sawah (Rattus argentiventer) di Desa Parakannyasag Kota Tasikmalaya". Jurnal Abdimas Kartika Wijayakusuma 1, No. 1, 2020, H.57.

Astuti, Widi.; \& Widyastuti, C.R, Pestisida Organik Ramah Lingkungan Pembasmi Hama Tanaman Sayur, Rekayasa 14, 2, 2017, h. 117.

Bahagia, "Manusia, lingkungan alam dan pembangunan, Suka Press UIN Sunan Kalijaga Press, 2014.

Bahagia, “Pembangunan Pertanian dalam Islam”, IPB Press, 2014.

Bahagia, B.; Mangunjaya, F.M.; Wibowo, R.; Rangkuti, Z.; Alwahid, M.A, "Leuit and prohibition forest: Indigenous knowledge of an Urug community resilience", dalam Harmoni Sosial: Jurnal Pendidikan 7, No. 2, 2020, H. 135.

Bahagia, Traditional Knowledge Of Urug Community For Climate, Conservation, And Agriculture, Mimbar: Jurnal Sosial Dan Pembangunan, 36, No.1, 2020. 
Diyah Krisna Yuliana, “Greenhouse Gas Emission Level In Indramayu District Tingkat Emisi Gas Rumah Kaca Di Kabupaten Indramayu", dalam Jurnal Sains Dan Teknologi Mitigasi Bencana, 12, No. 2, 2017.

Erbas, Bahar Celikkol.; \& Solakoglu, E.G, "In the Presence of Climate Change, the Use of Fertilizers and the Effect of Income on Agricultural Emissions", Jurnal Sustainability 9, No.1989, 2017.

Fachruddin Majeri Mangunjaya, Konservasi Lingkungan Dalam Islam, Pustaka Obor Indonesia, 2020.

Ichbal, P.; Citrawathi, D.M \& Dewi, N.P.R, "Nilai Palatabilitas Serangga Hama Bagi Kodok Buduk (Bufo Melanostictus) Serta Potensinya Dalam Mengendalikan Hama Serangga", Jurnal Pendidikan Biologi Undiksha, 5, No.3, 2018.

Indrihastuti, Dinik.; Murtilaksono, K.; \& Tjahjono, B, “Analisis Lahan Kritis Dan Arahan Rehabilitasi Lahan Dalam Pengembangan Wilayah Kabupaten Kendal Jawa Tengah", dalam Tata Loka 18 No. 3, 2016.

Khoiron, M.; \& Rezania, V, "Studi Literatur Tentang Pengaruh Penggunaan Media Monopoli Modifikasi Terhadap Hasil Belajar Ips Siswa Sekolah Dasar", Prosiding Seminar Nasional Rekarta 2020 Menciptakan Inovasi Pendidikan Melalui Kompetensi Pendidik Menuju Kemandirian Bangsa Di Era 5.0, 2020.

Made Sudarma \& Abd. Rahman As-syakur. “Dampak Perubahan Iklim Terhadap Sektor Pertanian Di Provinsi Bali", dalam Journal on Socio-Economics of Agriculture and Agribusiness 12, No.1, 2018.

Maharany, Rina, "Perbaikan Sifat Biologi Tanah Perkebunan Karet (Havea brasiliensis) Dengan Menggunakan Teknik Biopori”, dalam Jurnal Agrium, 16, No.2, 2019.

Mansur, "Dampak Sosial Penggunaan Pestisida Bagi Petani Persfektif Sosiologi Pedesaan", Al-Munzhir: Jurnal Kajian Ilmu Komunikasi dan Bimbingan Islam 6, No.1, 2013.

Marina, Flora.; Singkoh, O.; \& Katili, D.Y. "Bahaya Pestisida Sintetik (Sosialisasi Dan Pelatihan Bagi Wanita Kaum Ibu Desa Koka Kecamatan Tombulu Kabupaten Minahasa)", dalam Jurnal Anak Perempuan Indonesia 1, No.1, 2019.

Marzali, A, “Menulis Kajian Literatur”, Jurnal Etnosia, 01, No. 02, 2016.

Mudatsir Najamuddin, Strategi Mitigasi Emisi Gas Metan Pada Budidaya Padi Sawah. Jurnal Agribisnis, 8, No. 2, 2014.

Mujahidin, "Konsep Iqtha' Pemberian Tanah Kepada Masyarakat Dalam Pemikiran Ekonomi Al-Mawardi (Studi Kitab Al-Ahkam Alsultaniyyah)", Al-Amwal: Journal of Islamic Economic Law, 2, No. 2017. 
Nuraini, A.; Yuwariah, Y.; \& Rochayat, Y, "Pengembangan Produksi Pertanian Lahan Kering Dengan Sistem Low External Input Sustainable Agriculture (Leisa) Di Desa Cigadog, Dan Mandalagiri Kecamatan, Leuwisari Kabupaten Tasikmalaya", Jurnal Dharmakarya:Jurnal Aplikasi IPTEK untuk masyarakat, 4, No.2, 2015.

Nusantara, Abimanyu Dipo.; Bertham, Y.H.; Junedi, A.; Pujiwati, H.; \& Hartal, “Pemanfaatan Mikroba Untuk Meningkatkan Pertumbuhan Dan Hasil Kedelai Di Tanah Pesisir", Jurnal Ilmu Pertanian Indonesia, 21, No.1, 2019.

Nusantara, Abimanyu Dipo.; Bertham, Y.H.; Junedi, A.; Pujiwati, H.; \& Hartal, "Pemanfaatan Mikroba Untuk Meningkatkan Pertumbuhan Dan Hasil Kedelai Di Tanah Pesisir", dalam Jurnal Ilmu Pertanian Indonesia, 21, No.1, 2019.

Pendidikan Dan Sikap Dengan Praktik Penggunaan Alat Pelindung Diri (Apd) Pada Petani Bawang Merah, dalam Jurnal Kesehatan Masyarakat Indones 10, No. 2, 2015.

Primadani, D.K.; Istiaji, B.; Priyambodo, S.; Sanmas, A.A.; Fauzana, N.; Nurhawati, T.; Rosidah, A.; Ardella, A.; Rahmadhani, D.A.; Sukmawati, I.; Pratiwii, L.D, "Potensi Pemanfaatan Burung Hantu Sebagai Pengendalian Tikus Sawah di Desa Bener, Kecamatan Wonosari Kabupaten Klaten", dalam Jurnal Pusat Inovasi Masyarakat 2, 2, 2020, H.282.

Pusparini, M.D.; \& Suratha, I.K, Efektivitas Pengendalian Hama Tikus Pada Tanaman Pertanian Dengan Pemanfaatan Burung Hantu Di Desa Wringinrejo Kecamatan Gambiran Kabupaten Banyuwangi, Provinsi Jawa Timur, dalam Jurnal Pendidikan Geografi Undiksha, 6, No. 2, 2018.

Putra, Iwandikasyah.; \& Jalil, M, "Pengaruh Bahan Organik Terhadap Beberapa Sifat Kimia Tanah Pada Lahan Kering Masam", dalam Jurnal Agrotek Lestari 1, No. $1,2015$.

Rahmawanto.; Muhibuddin, D.G.A.; \& Aini, L.Q, “Pengaruh Faktor Abiotik Kimia Tanah Terhadap Supressifitas Tanah Dalam Mengendalikan Penyakit Layu Bakteri (Ralstonia Solanacearum) Pada Tanaman Tomat (Lycopersicon Esculentum Mill), Jurnal Hpt", 3, No. 2, 2015.

Ria Wulandari, Metode Kunjungan Lapangan Untuk Menanamkan Kepedulian Terhadap Lingkungan Hidup, Jurnal Pedagogia 5, No. 1, 2016, h. 73.

Sakiah.; Firmansyah, A.; \& Arfianti, D, "Sifat Biologi Tanah Pada Lahan Aplikasi dan Tanpa Aplikasi Tandan Kosong Kelapa Sawit di Adolina PT. Perkebunan Nusantara IV Soil Biological Characteristics on Land With and Without The Application of Oil Palm Empty Fruit Bunch At Adolina PT. Perkebunan Nusantara IV", Jurnal Penelitian Pertanian Terapan, 20, No. 1, 2020, h.12. 
Sari, M.; \& Asmendri, "Penelitian Kepustakaan (Library Research) dalam Penelitian Pendidikan IPA", Natural Science: Jurnal Penelitian Bidang IPA dan Pendidikan IPA, 6, No.1, 2020.

Setiabudi, j.; Izzati, M.; \& Kismartini, "Analisis Prioritas Kebijakan Pemanfaatan Burung Hantu (Tyto Alba) Sebagai Pengendalian Hama Tikus Sawah Yang Ramah Lingkungan Di Kabupaten Semarang", dalam Indonesian Journal of Conservation 04, No. 1,2015.

Setiawati, I.; A. Muharam.; A. Susanto.; E. Boes.; \& A. Hudayya, “PenerapanTeknologi Input Luar Rendah Pada Budidaya Cabai Merah untuk Mengurangi Penggunaan Pupuk dan Pestisida Sintetik (Implementation of Low External Input Technology for Chili Pepper Cultivation to Reduce Fertilizer and Synthetic Pesticide)", Jurnal hortikultura, 28, No. 1, 2018.

Sri Dwiastuti, "Pemberdayaan Lahan Kritis melalui Pola Interaksi Cacingtanah dengan Lingkungannya", Proceeding Biology Education Conference 14, No. 1, 2017.

Sukmawati, N.M.S.; Siti, N.W.; \& Candraasih, N.N. "Pengembangan Burung Hantu (Tyto Alba) Sebagai Pengendali Hama Tikus Di Desa Babahan Dan Senganan, Penebel, Tabanan, Bali", Buletin Udayana Mengabdi, 16, No. 1, 2017.

Sukmawati, N.M.S.; Siti, N.W.; Candraasih K, N.N, Pengembangan Burung Hantu (Tyto Alba) Sebagai Pengendali Hama Tikus Di Desa Babahan Dan Senganan, Penebel, Tabanan, Bali, dalam uletin Udayana Mengabdi, 16, No. 1, 2017.

Susilawati.; Mustoyo.; Budhisurya, E.; Anggono, R.C.W.; Simanjuntak, B.H, “Analisis Kesuburan Tanah Dengan Indikator Mikroorganisme Tanah Pada Berbagai Sistem Penggunaan Lahan Di Plateau Dieng, Agric, 25, No. 1, 2013, H. 66.

Suwandi, Sarwiji.; Yunus, A.; \& Etika, L. “Kecerdasan Ekologis Dalam Buku Sekolah Elektronik Mata Pelajaran Bahasa Indonesia Smp", Litera, 15, No. 1, h.26

Tarmeji, Achmad.; Shanti, R.; \& Patmawati, “Hubungan Bahan Organik dengan Keberadaan Fauna Tanah pada Umur Rehabilitasi Lahan Pasca Tambang yang Berbeda", Jurnal Agroekoteknologi Tropika Lembab, 1, No. 1, 2018.

Tjahjono, H.K, "Studi Literatur Pengaruh Keadilan Distributif dan Keadilan Prosedural Pada Konsekuensinya Dengan Teknik Meta Analisis", Jurnal Psikologi, 35, No.1, 2015.

Utari, S.N.; Haneda, N.F.; Kusrini, M.D, “Potensi Kodok Buduk (Duttaphrynus Melanostictus Schneider 1799) Sebagai Pengendali Alami Hama Di Daerah Urban", 25, No.1, 2020. 
Vilar Mawa Miana \& Cahyo Suraji. "Penggunaan Pestisida Berhubungan Dengan Iritasi Kulit Pada Petani Padi", dalam urnal Ilmiah Permas: Jurnal Ilmiah STIKES Kendal 10, No.1, 2020.

Wati, M; \& Hidayat, Y, "Komposisi Makanan (Diet) Dua Spesies Kodok Bufo Melanostictus, Schneider (1799) Dan Bufo Asper, Gravenhorst (1829) Di Daratan Tinggi Dan Dataran Rendah Sumatera Barat", jurnal pelangi, 6, No.2, 2014.

Werembinan, C.S.; Pakasi, C.B.D.; \& Pangemanan, L.R.J. “Persepsi Generasi Muda Terhadap Kegiatan Pertanian Di Kelurahan Buha Kecamatan Mapanget Kota Manado", Dalam Agri-SosioEkonomi Unsrat, 14, No. 3, 2018.

Wiwi Yuliyanah \& Wulandari Meikawati, "Hubungan Pengetahuan Tentang Bahaya Pestisida, Pendidikan Dan Sikap Dengan Praktik Penggunaan Alat Pelindung Diri (Apd) Pada Petani Bawang Merah", dalam Jurnal Kesehatan Masyarakat Indones 10, No. 2, 2015. 